\title{
Bone Changes in Femoral Bone of Mice Using Calcein Labeling
}

\author{
Moon-Jung Shim \\ Department of Clinical Laboratory Science, Ansan University, Ansan 15328, Korea
}

\section{Mice에서 Calcein 표지를 이용한 골 변화 관찰}

\author{
심문정 \\ 안산대학교 임상병리과
}

\begin{abstract}
In vivo labeling of bone with fluorochromes is a widely used method for assessment of bone formation and remodeling processes. In particular, calcein is used as a marker for identification of bone growth, which is indicated by a green color. Calcein green is a calcium chelator that adheres to regions of mineralizing bone thereby allowing localization of new bone. Bone formation and remodeling in vivo can be assessed by calcium-binding calcein labeling. In this study, changes in the femoral bone of a normal mouse model at both 4 and 8 weeks were evaluated using calcein labeling. Intense deposition of calcium in the bone was observed after application for 8 weeks. A mouse model is suitable for application in in vivo experiments using genetically modified mice, such as knock-out mice, however data regarding femoral cross sectional bone in young mice are limited. The current study confirmed calcein as a useful marker for identification of bone growth, which was indicated by a green color on photomicrographs. This methodological process may provide basic information for interpreting bone formation and regeneration to pharmacologic or genetic manipulation in mice.
\end{abstract}

Keywords: Calcein green, Bone formation, Mice, Fluorochrome

This is an Open Access article distributed under the terms of the Creative Commons Attribution Non-Commercial License (http://creativecommons.org/licenses/by-nc/4.0) which permits unrestricted non-commercial use, distribution, and reproduction in any medium, provided the original work is properly cited.

Copyright ( 2016 The Korean Society for Clinical Laboratory Science. All rights reserved.
Corresponding author: Moon-Jung Shim Department of Clinical Laboratory Science, Ansan University, 155 Ansandaehak-ro, Sangrok-gu, Ansan 15328, Korea Tel: 82-31-400-6938 Fax: 82-31-363-7702 E-mail: mjshim@ansan.ac.kr

Received: April 28, 2016 Revised $1^{\text {st: }}:$ May 11, 2016 Revised $2^{\text {nd }}:$ May 12, 2016 Accepted: May 12, 2016

\section{Introduction}

Bone in a live skeletal system constantly changes. Approximately $7.5 \%$ of bone turnover occurs annually. Bone modeling and remodeling are inherently involved in the alteration of bone. Traditional methods of in vivo bone growth evaluation in small animal models utilize noninvasive radiological, nuclear, and bioluminescence imaging methods. However, these do not allow detailed examination of the tissue. Fluorochrome labeling is a widely used standard technique in skeletal research, which is simple and efficient for the investigation of the dynamics of bone formation in combination with plain histology [1,2]. The use of fluorochrome labeling techniques for in vivo bone studies is not a new development. In 1956, the first application of fluorochromes in vivo experiments was reported [3].

Bone formation and remodeling in vivo can be assessed by polychrome labeling using calcium-binding fluorescent dyes. Newly forming bone tissue can be measured after vital staining with fluorochromes, such as calcein or tetracycline, which forms fluorescent complexes with calcium and can be measured with a high accuracy by use of a fluorescence 
microscope. Calcein green is a calcium chelator that adheres to regions of mineralizing bone thereby permitting localization of new bone.

In human studies, for examples, fluorochromes are used for the assessment of cancellous or endocortical bone turnover in iliac bone biopsies [4]. In animal research this technique is used for a much broader range of applications such as the measurement of the cancellous or endocortical, intracortical, and periosteal bone formation rate for the evaluation of bone elongation and for the assessment of bone resorption [5,6]. However, most previous studies were performed in rats [7-9], rabbits [10], and dogs [11] because bone of mice is brittle than other animals. Even though mice were used in the histological study, tibia bone [12] or longitudinal sections [13] were common. Therefore, in this study, 2 month old young mice were utilized and femurs were cross-sectioned at the mid-diaphysis.

The aim of the present investigation is to evaluate the deposition of calcium at both 4th and 8th weeks in the femoral bone of normal mice model using calcein labeling.

\section{Materials and Methods}

Mice were labeled by with calcein ( $25 \mathrm{mg} / \mathrm{kg}$; Sigma-Aldrich Co., St. Louis, MO, USA) in PBS every 5 days for 4-week-old mice, 7 days for 8-week-old mice by intraperitoneal injection, and 2 days prior to sacrifice. All procedures were approved by the Institutional Animal Care and Use Committee of Ohio State University.

Femurs were dissected, fixed in 70\% ethanol and femoral bone sections were obtained using a low speed saw with two parallel diamond blades cutting under water irrigation. The sections were dehydrated at $4^{\circ} \mathrm{C}$ in alcohol solution up to $100 \%$ ethanol and infiltrated in a media containing methyl methacrylate for $24 \mathrm{hr}$ under vacuum. And then polymerization was started by warm water heating of the samples. After polymerization, the polymethyl methacrylate blocks were exposed to the UV light source for 1 week in refrigerator and sectioned about $80 \mu \mathrm{m}$ thick using a Leica SP 1600 microtome (Leica Microsystems, Nussloch, Germany), To mount the glass slide, a UV light curing glue was used because of its short curing time and high bond strength. Calcein levels on the surface of bone were analyzed using a Olympus DP 70 fluorescence microscope (Olympus America Inc., Center Valley, PA, USA).

\section{Results}

With the vital labeling technique, the new forming bone area was marked with the calcein-calcium complex, which can be seen in a fluorescence microscope. Therefore with this technique it is possible to determine the new bone area qualitatively and quantitatively.

In this study, calcein green labeling has confirmed the presence of newly formed bone tissue. And calcein has a high calcium affinity which translates into a relatively broad fluorescent band. After 4 and 8 weeks, microscopic analyses of the surfaces verified as good new bone formation which showed that new bone was formed as a surface-related phenomenon. The double layer after 8 weeks were observed broader than 4 weeks, and showed intense deposition of calcium in the bone after the application of 8 weeks (Fig. 1,2). It means that was deposited at the site of active mineralization.

These days this technique of fluorochrome labeling is used in order to investigate bone formation and remodeling processes in vivo at different time interval.

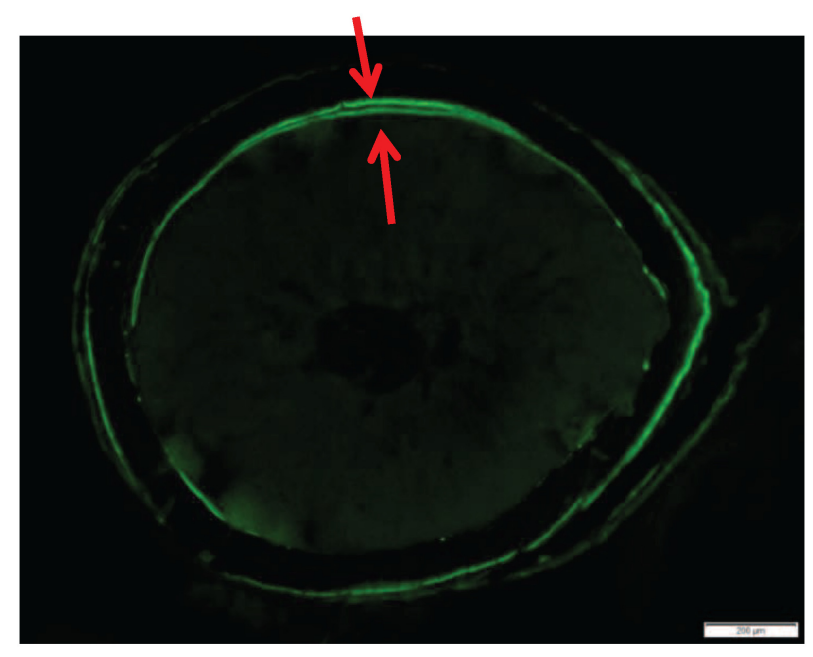

Fig. 1. Fluorescence image of the femoral cross-section at 4-week-old-mouse. Bone formation was visualized by double calcein labeling in the femoral bone. Representative picture: $\times 10$, scale bar: $200 \mu \mathrm{m}$. 


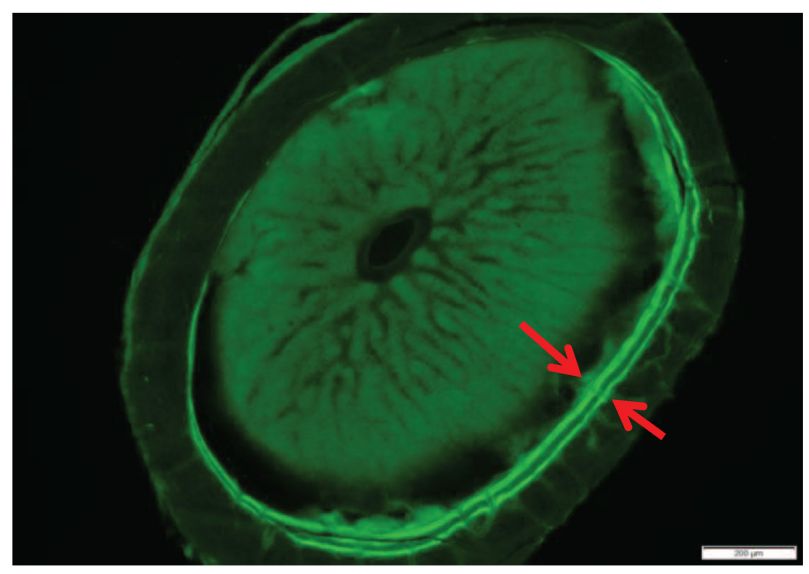

Fig. 2. Fluorescence image of the femoral cross-section at 8-week-old-mouse. Bone formation was visualized by double calcein labeling in the femoral bone. Representative picture: $\times 10$, scale bar: $200 \mu \mathrm{m}$.

\section{Discussion}

Histomorphometry is the gold standard method for the assessment of bone remodeling. Although other methods, such as serum or urine biomarkers, can provide whole body estimates of remodeling, only histology can provide site-specific remodeling data. In vivo labeling of bone with fluorochromes is a widely used method to assess mineral apposition rate and bone formation rate in bone histomorphometry [14-16]. In sections of undecalcified bone, fluorochromes can be visualized by their specific fluorescence under UV excitation. Prologed exposure to UV light results in irreversible fading of fluorochromes bound to bone mineralization sites. Therefore, possible fading of fluorochromes precludes the use of light for polymerization of the methacrylate in a routine plastic embedding of undecalcified bones suitable for both bone histomorphometry and histochemical and immunohistological techniques.

Fluorochrome labels, when bound to calcium ions, can be incorporated at sites of mineralization in the form of hydroxyapatite crystals [17]. This means that the label indicates all sites of bone formation or dentin deposition, and hypertrophic cartilage in the growth plate. In the first 24 36 $\mathrm{hr}$ after administration, the label is stabilized. As a result, the fluorescent label demarcates the mineralization front at the time of administration and can be detected in histological sections without any further staining or decalcification.

During growth, bone continually undergoes changes of shape and structure. Accretion in length and thickness, modeling, and drift activities lead to different morphologies and determine the relative position among various skeletal parts. After completion of growth, pathological processes, aging, and degeneration are responsible for structural alterations, and healing processes and adaptation to new functional demands require new structural characteristics. Certain stains are able to bind to sites, which are calcifying. These stains stay there for a long time and serve as markers, allowing the identification of tissues, which are mineralized at the time of dye administration.

Animal models are commonly used in the study of skeletal biology and serve as useful tools to delineate mechanisms underlying bone loss and skeletal fragility. Bone-seeking fluorochromes provide a useful tool for analyzing changes of bone morphology. The presence of the fluorochromes indicates site, time and amount of bone deposition, and enhances the information continued in bone specimens. The administration of several fluorochromes, distinguishable by color, offers distinct advantages over single labels. With the method of vital labeling, bone forming areas can be measured. The apposition rate was calculated from the distance between the periosteal surface and the first calcein injection line for the first two time points of sacrifice of each group. Mice are used widespread in biological studies of musculoskeletal disease. It is possible to determine parameters, such as mineral apposition rate, mineralizing surface, and bone formation rate. However, unfortunately in this study, mice were too young and bone were easy breaking to determine parameters.

As I mentioned, most previous studies were performed in rats, rabbits, and dogs because bone of mice is brittle. However mice model can obtain significant experimental results within a short period, incurring less side effects, and be suitable to apply in vivo experiment using genetically modified mouse such as knock-out mouse.

In this study, calcein has been confirmed as a marker for the identification of bone growth, which is indicated by the green color on the photomicrographs in the femoral bone of 
4-week, 8-week old normal mice model. Furthermore, examining human bone biopsies has shown different fluorochromes have different binding affinities, so other fluorochromes should be studied, including tetracycline which is used clinically. This methodological progress may provide basic information for interpreting the bone formation and regeneration to pharmacologic or genetic manipulation in mice.

\section{요 약}

골은 일생에 걸쳐 지속적인 재형성과장을 거치면서 유지되고 이 러한 기전에 대한 연구는 골다공증을 비롯한 골대사 질환의 병태생 리와 치료에 있어 큰 진전을 이루고 있다. 특히 생체 내 골형성 및 재 생과정을 연구하는데 있어 형광표지자를 이용하는 방법이 널리 알 려져 있는데, 그 중 calcein은 칼슘 킬레이터로 골이 새롭게 형성하 는 부위에 녹색을 뜸으로써 유용한 마커로 사용된다. 그러나 대부 분의 골형성 연구에서 실험동물의 경우 표본제작을 할 때 크기가 작고 뼈가 부숴지기 쉬워 rat이나 rabbit을 이용하였으며, mice의 femur를 cross-section해서 관찰한 연구는 거의 없는 실정이다. 그래서 본 연구에서는 어린 mice를 실험동물로 이용하였으며, 생 체 내 calcein을 4주간, 8 주간 투여한 후 골 형성 변화를 형광현미 경으로 관찰한 결과 8주차 쥐에서 4주차보다 진하고 골 형성 간격 도 넓게 관찰된 것을 확인 할 수 있었다. Mice는 빠른 시일 내에 결 과를 얻을 수 있고 부작용이 적은 장점이 있어서 앞으로 knock-out mice를 이용한 생체 내 실험에 활용하기 적합하다고 생각되며, 골 형성 속도 평가 등 다양한 분야에서의 골 형성과 재생연구에 있어 기초 정보를 제공할 것으로 기대한다.

\section{Acknowledgements: None}

Funding: None

Conflict of interest: None

\section{References}

1. Solheim T. Pluricolor fluorescent labeling of mineralizing tissue. Scand J Dent Res.1974;82:19-27.

2. Schicker M, Pautke C, Reitz K, Hemraj I, Neth P, Mutschler W, et al. The use of four-colour immunofluorescence techniques to identify mesenchymal stem cells. J Anat. 2004;204:133-139.

3. Andre T. Studies on the distribution of tririum-labelled dihydrostreptomycin and tetracycline in the body. Acta Radiol. 1956; 142:1-89.

4. Recker RR, Kimmel DB, Parfitt AM, Davies KM, Keshawarz N, Hnders S. Static and tetracycline-based bone histomorphometric data from 34 normal postmenopausal females. J Bone Miner Res. 1988;3:133-144.

5. Turner RT. Cancellous bone turnover in growing rats: time-dependent changes in association between calcein label and osteoblasts. J Bone Miner Res. 1994;9:1419-1424.

6. Turner RT, Evans GL, Wakley GK. Mechanism of action of estrogen on cancellous bone balance in tibiae of ovariectomized growing rats: inhibition of indices formation and resorption. J Bone Miner Res. 1993;8:359-366.

7. Erben RG, Embedding of bone samples in methyl methacrylate: An improved method suitable for bone histomorphometry, histochemistry, and immunohistochemistry. J Histochem \& Cytochem. 1997;45(2): 307-313.

8. Sontag W. Age-dependent morphometric alterations in the distal femora of male and female rats. Bone. 1992;13:297-310.

9. Ames MS, Hong SM, Lee HR, Fields HW, Johnston WM, Kim DG. Estrogen deficiency increases variability of tissue mineral density of alveolar bone surrounding teeth. Arch Oral Biol. 2010;55(8): 599-605.

10. Gehrke SA, Nascimento PC. Analysis of bone tissue healing around titanium implant surface treated with Tio Sandblasted after three and six weeks used different histological methods-a study in rabbits. Sci J Med \& Clin Trials. 2013;34-40.

11. Deguchi T, Yamamoto TT, Yabuuchi T, Ando R, Roberts WE, Garetto LP. Histomorphometric evaluation of alveolar bone turnover between the maxilla and the mandible during experimental tooth movement in dogs. Am J Orthodon \& Dentofacial Orthopedics. 2008; June:133(6):889-897.

12. Aido M, Kerschnitzki M, Hoerth R, Burghammer M, Montero $\mathrm{CD}$, Checa S, et al. Relationship between nanoscale mineral properties and calcein labeling in mineralizing bone. Connect Tissue Res, 2014; 55:15-17.

13. Glatt V, Canalis E, Stadmeyer L, Bouxsein M. Age-related changes in trabecular architecture differ in female and male C57BL/6J mice. J Bone and Mineral Res. 2007;22(8):1197-1207.

14. Roldan JC, Jepsen S, Miller J, Freitag S, Rueger DC, Acil Y, et al. Bone formation in the presence of platelet-rich plasma vs. bone morphogenetic proten-7. Bone. 2004;34:80-90.

15. Frost HM, Villanueva AR, Roth H, Stanisavljevic S. Tetracycline bone labeling. J New Drugs. 1961;1:206-216.

16. Follak N, Kloting I, Wolf E, Merk H. Histomorphometric evaluation of the influence of the diabetic metabolic state on bone defect healing depending on the defect size in spontaneously diabetic BB/OK rats. Bone. 2004;35:144-152.

17. Rahn BA, Perren SM. Xylenol orange, a fluorochrome useful in polychrome sequential labeling of calcifying tissues. Stain Technol. 1971;46:125-129. 